\title{
GEOPHYSICAL APPLICATIONS IN MAPPING THE SUBSURFACE STRUCTURE OF ARCHAEOLOGICAL SITE AT LEMBAH BUJANG, KEDAH, MALAYSIA.
}

SARMIZA MOHAMED SAPIAI

\section{UNIVERSITI SAINS MALAYSIA}

2011 
GEOPHYSICAL APPLICATIONS IN MAPPING THE SUBSURFACE STRUCTURE OF ARCHAEOLOGICAL SITE AT LEMBAH BUJANG, KEDAH, MALAYSIA

by

SARMIZA MOHAMED SAPIAI

Thesis submitted in fulfilment of the requirements for the degree of Master of Science 


\section{ACKNOWLEDGEMENTS}

Life is endeavor, as well as the making of this thesis. Praise to Allah. First of all, I would like to thanks my main supervisor, Dr. Rosli Saad who always at his best assisting me, generously be there whenever I need help, also my co-supervisor Assoc. Prof. Dr. Mohd. Nawawi Mohd Nordin for being supportive and give his great help all the time. Dr. Mokhtar Saidin from Center for Global Archaeological Research (CGAR) greatly helps me with the archaeological aspect and providing so much information whenever possible. Also thanks to Mr. Khairul Ariffin Mohd Noh who guide me mostly for the gradiometer magnetic method which I started from almost zero.

My million thanks also goes to Geophysics lab staff Mr. Zainul Abidin, Mr. Yaakob Othman, Mr. Shaiful Mahathir Ismail and Mr. Low Weng Leng for scarifying their times and energy assisting me in the project.

Special thanks to fellow friends in Geophysics study, Ms Nordiana Muztaza, Ms Zuriati Jusoh, Ms Nur Azwin Ismail, Ms Noer El Hidayah Ismail and to Master Students from CGAR, Naizatul Akma Mokhtar. My special thanks also go to the Research Assistant; Mr. Shyeh Sahibul Karamah Masnan for all the maps redrawing and generous helps. Those guys who sweats a lot during data acquisitions, Mr. Faizan Akasyah Ghazali, Mr. Muhammad Izzuljad Ahmad Fuad and Mr. Nik Nurhalim Che Soh. Without them, this research will never accomplish this great.

Further, I would like to express my thanks to my parents En. Mohamed Sapiai and Puan Kamariah, also to my parents-in-law, Tuan Haji Malit and Puan Hajjah Shmsiah, and the whole family members for their supporting and understanding during my study. 
Last but the most important, to my husband and my lifetime companion also the sponsor, Mr. Khairuz Zharfan, to my son and source of inspiration, Muhammad Zharif Adlan for the endless love, patience and comfort during this challenging time. For my second baby who is inside my womb; thanks for the strength and spirit you gave me.

And the list goes on, for those who are involved in this project; apologize not to state your name here. Thanks for all the contributions.

I dedicate this thesis to all of you!

SARMIZA MOHAMED SAPIAI

2011 
ACKNOWLEDGEMENTS

TABLE OF CONTENTS

iv

LIST OF TABLES

vii

LIST OF FIGURES

viii

LIST OF SYMBOLS

xiv

LIST OF ABBREVIATION

XV

ABSTRAK

xvi

ABSTRACT

xvii

CHAPTER 1 : INTRODUCTION

1.0 Background

1

1.1 Importance of archaeology

2

1.2 Non-destructive prospecting

3

1.3 Geophysics in archaeology

1.4 Statement of problem

1.5 Objective of study

1.6 Scope of study

1.7 Layout of thesis

1.8 Chapter summary

$\begin{array}{lll}2.0 & \text { Introduction } & 17\end{array}$

$\begin{array}{lll}2.1 & \text { Previous study } & 17\end{array}$

$\begin{array}{lll}2.2 & \text { Study area } & 26\end{array}$

2.3 History of Lembah Bujang 30

2.4 Regional geology of Lembah Bujang $\quad 32$

2.4.1 Geomorphology of Lembah Bujang $\quad 36$

$\begin{array}{ll}2.4 .2 \text { Iron } & 36\end{array}$

2.4.3 Evidence of higher Holocene sea-level $\quad 37$

2.5 Chapter summary 42

CHAPTER 3 : MATERIALS AND METHODS 43

3.0 Introduction 43

3.1 Magnetic gradiometer method 43

3.1.1 Advantages and disadvantages of gradiometer $\quad 45$

$\begin{array}{ll}\text { 3.1.2 Magnetic gradiometer and gradient techniques } & 47\end{array}$

$\begin{array}{lll}3.1 .3 & \text { Earth's magnetic field } & 47\end{array}$ 
3.1.3.1 Magnetic dipoles 49

3.1.3.2 Magnetic susceptibility 49

3.1.4 Archaeological exploration $\quad 50$

3.1.4.1 Magnetic anomalies of archaeological origin 51

3.1.4.2 Remanent magnetization 51

3.1.4.3 Thermoremanent magnetism $\quad 52$

3.2 2-D resistivity method 53

3.2.1 General principle $\quad 54$

3.2.2 Resistivity survey $\quad 56$

3.2.3 The relationship between geology and resistivity value 58

3.2.4 Pseudosection data plotting method 59

3.2.5 Advantages and disadvantages of the chosen arrays 60

$\begin{array}{lll}3.2 .6 & \text { Roll-along technique } & 62\end{array}$

3.2.7 Archaeological exploration 63

3.2.8 Effectiveness of magnetic and resistivity methods 63

$\begin{array}{lll}3.3 & \text { Ground Penetrating Radar } & 64\end{array}$

3.3.1 General principles $\quad 65$

$\begin{array}{lll}3.3 .2 & \text { Conductivity } & 67\end{array}$

$\begin{array}{lll}3.3 .3 & \text { Dielectric constant } & 68\end{array}$

3.3.4 Electrical properties of rocks, soils and fluids $\quad 70$

$\begin{array}{lll}3.4 & \text { Field Methodology } & 71\end{array}$

3.4.1 Gradiometer method $\quad 73$

$\begin{array}{ll}3.4 .2 \text { 2-D resistivity method } & 75\end{array}$

3.4.3 Ground Penetrating Radar (GPR) method 77

$\begin{array}{lll}3.5 & \text { Data acquisition at Sungai Batu } & 78\end{array}$

$\begin{array}{lll}3.5 .1 & \text { Gradiometer survey } & 78\end{array}$

$\begin{array}{lll}3.5 .2 & \text { 2-D resistivity survey } & 79\end{array}$

$\begin{array}{ll}\text { 3.5.3 Ground Penetrating Radar survey } & 80\end{array}$

$\begin{array}{lll}3.6 & \text { Data acquisition at Sungai Bujang } & 81\end{array}$

$\begin{array}{lll}3.6 .1 & \text { Gradiometer survey } & 81\end{array}$

$\begin{array}{lll}3.6 .2 & 2-D \text { resistivity survey } & 82\end{array}$

3.6.3 Ground Penetrating Radar survey 83

$\begin{array}{lll}3.7 & \text { Data Processing } & 83\end{array}$

$\begin{array}{lll}3.8 & \text { Current archaeological works at Lembah Bujang } & 84\end{array}$

$\begin{array}{lll}3.9 & \text { Chapter summary } & 84\end{array}$

CHAPTER 4 : RESULTS AND DISCUSSION 86

$\begin{array}{lll}4.0 & \text { Introduction } & 86\end{array}$

$\begin{array}{llr}4.1 & \text { Results } & 86\end{array}$

4.1.1 Sungai Batu $\quad 86$

4.1.1.1 Magnetic gradiometer results $\quad 87$

$\begin{array}{ll}\text { 4.1.1.2 2-D resistivity results } & 89\end{array}$

4.1.1.3 Ground penetrating radar results $\quad 94$

$\begin{array}{ll}\text { 4.1.1.4 Borehole records } & 100\end{array}$

4.1.1.5 Correlation of borehole records and geophysics 103 data 
$\begin{array}{lll}\text { 4.1.2 Sungai Bujang } & 105\end{array}$

4.1.2.1 Magnetic gradiometer results 109

4.1.2.2 2-D resistivity results 114

4.1.2.3 Ground penetrating radar results 116

$\begin{array}{lll}4.2 & \text { Discussions } & 119\end{array}$

$\begin{array}{lll}4.3 & \text { Accuracy of geophysical methods } & 123\end{array}$

\begin{tabular}{ll}
4.4 & Limitation of the study \\
\hline & 124
\end{tabular}

$\begin{array}{lll}4.5 & \text { Chapter summary } & 125\end{array}$

CHAPTER 5 : CONCLUSION AND RECOMMENDATIONS 125

$\begin{array}{lll}5.0 & \text { Introduction } & 128\end{array}$

$\begin{array}{lll}5.1 & \text { Conclusion } & 128\end{array}$

$\begin{array}{lll}5.2 & \text { Suggestion for future research } & 130\end{array}$

$\begin{array}{lr}\text { REFERENCES } & 132\end{array}$

APPENDICES

APPENDIX A: Geological Map of Peninsular Malaysia 139

APPENDIX B: List of instruments used for Magnetic gradiometer, 141

2-D Resistivity and GPR methods.

APPENDIX C: Refer to CD (Attach). Magnetic gradiometer, 2-D 144

Resistivity and GPR data.

APPENDIX D: List of Published Paper 145 


\section{LIST OF TABLES}

\section{Page}

Table 1.1 Summary of applications for common surface geophysical techniques (Technos, 2004).

Table 2.1 Sea level fluctuations stages which were entirely an eustatic nature (After Walker, 1956).

Table 3.1 Applications of the magnetic method (After Mickus, 2009).

Table 3.2 Resistivity values of some common rocks and soil materials (After Keller and Frischknecht, 1966 and Nath et al., 2000).

Table 3.3 The advantages and limitation of GPR applications (After Sheriff, 2002).

Table 3.4 Typical dielectric constant, conductivity and velocity value of common materials and medium (After Beres and Haeni, 1991).

Table 4.1 Summary list and information of borehole records in Sungai Batu (After Mokhtar, 2009). 


\section{LIST OF FIGURES}

Page

Figure 2.1 Location of Kedah in Malaysia and Southeast Asia 27 (After Khoo, 1996).

Figure 2.2 Map of Lembah Bujang, with ancient site as marked by Wales (1940). Sungai Batu and Sungai Bujang have been highlighted with red circle.

Figure 2.3 Comparison of satellite image (Google Earth, 2010) and geological map of study area (Tate et. al, 2008). The red line indicates the location of Sungai Bujang and the green line indicates border of Jerai Mountain (Map legends and information can be referred to Appendix A).

Figure 2.4 Sungai Batu study area boundary by coordinates (Google Earth, 2010).

Figure 2.5 Geology map of study area in southern Kedah (Maps of Peninsular Malaysia $8^{\text {th }}$ (ed), 1985).

Figure 2.6 Changes in Holocene sea level for 6000 B.P. in south East Asia with amplitude of approximately $2 \mathrm{~m}$ and decreasing (indicated by the zone between the dashed straight lines). Points represent indicators of the seaside age that has been determined by radiocarbon methods. Original information listed in Tjia et al. (1977).

Figure 2.7 Holocene sea-level movements (After Umbgrove, 1938).

Figure 3.1 Generalized cross section of the Earth's magnetic field (After Grant and West, 1965).

Figure 3.2 Acquisition of thermoremanent magnetism in the Earth's magnetic field, H. (a) In unfired clay, the magnetic domains are randomly orientated so that the nett magnetic moment is zero. (b) At elevated temperatures the direction of the magnetic domains can reverse so that they have a component parallel rather than anti-parallel to the magnetic field, $\mathrm{H}$. Hence in the fired clay, there is a nett magnetic moment parallel to $\mathrm{H}$ (After Tite, 1972).

Figure 3.3: Typical magnetic anomalies of common archaeological features (After Breiner, 1999). 
Figure 3.4 A conventional four electrode array to measure the subsurface resistivity (After Loke, 1999).

Figure 3.5 Common arrays used in resistivity surveys and their 55 geometric factors (After Loke, 1999).

Figure 3.6 Resistivity measuring of a cube of side length, L using two current and potential measuring electrodes (After Blaricom, 1980).

Figure 3.7 The three different models used in the interpretation of resistivity measurements (After Loke, 1999).

Figure 3.8 The resistivity range of some geological materials (After Sheriff, 2002).

Figure 3.9 The arrangement of electrodes for a 2-D electrical survey and the sequence of measurements used to build up a pseudosection (After Loke, 1999).

Figure 3.10 Arrangement of the electrodes for the Dipole-dipole, Pole-dipole and Wenner-Schlumberger arrays, together with the definition of the "a" spacing and the " $n$ " factor for each array (After Loke, 2000).

Figure 3.11 The use of the roll-along method to extend the area covered by a survey (After Loke, 2000).

Figure 3.12 Comparison of effectiveness between magnetometer and resistivity survey for archaeological prospecting (After Greene, 1995).

Figure 3.13 Electromagnetic wave propagation. An electromagnetic wave consists of conjoined electrical and magnetic waves that feed on themselves during propagation (After Conyers, 2004).

Figure 3.14 GPR schematic (After Rittenhouse J., 2008). 68

Figure 3.15 View at site SB2A mound before excavation work, while the geophysical study was still in progress.

Figure 3.16 Example of surface finds that can be seen all over the mound in SB2A. This sample was later identified as tuyère (French word), known as a nozzle through which air is forces into a smelter, furnage or forge.

Figure 3.17 Fragments of clay bricks are everywhere on the ground before excavation at site SB1A and SB1B. 
Figure 3.18 Proton magnetometer G-856; (a) operational, (b) console.

Figure 3.19 The arrangement of electrodes for a 2-D electrical imaging survey and the sequence of measurements used to build up a pseudosection (After Loke, 1997).

Figure 3.20 Cable array for ABEM instrument with four cables (After ABEM, 2009).

Figure 3.21 Data coverage of Pole-dipole (long) and Pole-dipole (short) array (After ABEM, 2009).

Figure 3.22 GPR cart with $250 \mathrm{MHz}$ shielded antenna.

Figure 3.23 Geophysical survey lines at the Sungai Batu. 2-D Resistivity (yellow), gradiometer (green) and GPR (blue).

Figure 3.24 Complete set up equipment for 2-D resistivity survey, at line survey LB003.

Figure 3.25 Study area at Sungai Batu marked as green boxes. Sites SB1A, SB1B and SB2A are discussed.

Figure 3.26 Survey line of GPR at Sungai Batu marked with blue lines. Purple boxes are current Center for Global Archaeological Research's excavation trench where the candi have successfully founded (Google, 2010).

Figure 3.27 Data acquisition for gradiometer survey, differentiate by region 1 and region 2 .

Figure 3.28 Gradiometer survey at Sungai Bujang. (a) Region 1, the sensor spacing is $1.8 \mathrm{~m}$; (b) Region 2 the sensor spacing is $0.9 \mathrm{~m}$.

Figure 3.29 GPR survey at Sungai Bujang, nearby the paddy field.

Figure 4.1 Magnetic anomaly map for Sungai Batu area. 87

Figure 4.2 Anomaly map from magnetic survey done by CGAR. 88

Figure 4.3 2-D Resistivity line LB001 until LB006 locations 89 (Google Earth, 2009).

Figure 4.4 GPR and resistivity survey line at SB1A and SB2A site.

Figure 4.5 The 2-D resistivity imaging section for (A) LB001 and (B) LB002 at Sungai Batu. 
Figure 4.6 Hard surface at the vicinity of Sungai Batu study area,

Figure 4.7 Fine sand observed at surface of Sungai Batu area, this example is from vicinity of survey line LB002.

Figure 4.8 The 2-D resistivity imaging section for (A) LB003 and (B) LB004 at Sungai Batu.

Figure 4.9 The 2-D resistivity imaging section for (A) LB005 and (B) LB006 at Sungai Batu.

Figure 4.10 The 2-D resistivity imaging section for LBJ04 at Sungai Batu.

Figure 4.11 GPR section for M1.

Figure 4.12 GPR section for M2. 95

Figure 4.13 GPR section for M3. 95

$\begin{array}{lll}\text { Figure 4.14 GPR section for M4. } & 95\end{array}$

$\begin{array}{lll}\text { Figure 4.15 } & \text { GPR section for M5. } & 96\end{array}$

Figure 4.16 One of the samples from SB2A site trench J6, identified 96 as iron slag found at depth of $60 \mathrm{~cm}$ from ground.

Figure 4.17 Fraction of tuyere associated with iron slags, also at depth of $60 \mathrm{~cm}$ at SB2A site in trench J6. View from (A) side, (B) front of tuyere sample.

Figure 4.18 GPR survey line at site SB1A and SB1B.

Figure 4.19 Cross section of GPR line Z1. 98

$\begin{array}{lll}\text { Figure 4.20 } & \text { Cross section of GPR line Z2. } & 98\end{array}$

Figure 4.21 Cross section of GPR line Z3. 99

Figure 4.22 Cross section of GPR line Z4. 99

$\begin{array}{lll}\text { Figure 4.23 Sub-surface cross section for Line A-A'. } & 101\end{array}$

$\begin{array}{lll}\text { Figure 4.24 Sub-surface cross section for Line B-B'. } & 101\end{array}$ 
Figure 4.25 Locations of 11 boreholes around Sungai Batu marked in purple colour font. Yellow line is resistivity line LB006 and blue lines for GPR survey line Z1 until Z5.

Figure 4.26 The 2-D resistivity imaging section of LBJ04 compared to anomalies on shallow part of GPR data Z2 (Site SB1A).

Figure 4.27 General location of survey area along Sungai Bujang, which is divided into region 1 and 2 for gradiometer survey.

Figure 4.28 Study area was divided to five sites to see the area in more detail especially for line resistivity and ground penetrating radar study.

Figure 4.29 Survey location at Site 1, where only gradiometer and GPR survey done.

Figure 4.30 Survey location at Site 2. GPR line survey line done by grid $8 \times 8$ lines.

Figure 4.31 Survey location at Site 3.

Figure 4.32 Survey location at Site 4.

Figure 4.33 Survey location at Site 5.

Figure 4.34 Gradiometer survey anomaly contour map for region 1.

Figure 4.35 Gradiometer survey anomaly contour map for region 1 with the zone of interest.

Figure 4.36 Gradiometer contour overlaid with area map for region 1, Sungai Bujang.

Figure 4.37 Gradiometer survey anomaly contour map for region 2.

Figure 4.38 Anomaly contouring for region 2 marked with zone of interest.

Figure 4.39 Gradiometer contour overlaid with area map for region 2.

Figure 4.40 The 2-D resistivity imaging section for R1 at Sungai Bujang.

Figure 4.41 The 2-D resistivity imaging section of R8 at Sungai Bujang. 
Figure 4.42 The 2-D resistivity imaging section for R11 at Sungai Bujang.

Figure 4.43 GPR image from Site 1 line G3_S3 (JM3). 116

Figure 4.44 GPR image from Site 1 line G3_S17 (JM17). 116

Figure 4.45 GPR image from Site 2 line G1_S11 (SG11). 117

Figure 4.46 GPR image from Site 2 line G1_S19 (SG19) 117

Figure 4.47 GPR image from Site 3 line G6_S3 $(\mathrm{Pb} 3) . \quad 118$

Figure 4.48 GPR image from Site 4 lineG9_S41 (JD41). 118

Figure 4.49 GPR image from Site 4 line G11_S6 (LSB12). 119

$\begin{array}{lll}\text { Figure 4.50 Surface finding at Site SB1A were mostly tuyere } & 120\end{array}$ fragments, which leads to the excavation work.

Figure 4.51 One of the surface find found at Site SB1A; a brick sample.

Figure 4.52 Sample of brick from the site being analysed under the microscope in the lab test procedure exhibit that the brick was made from clay and sand. This sample has also associated with quartz and iron oxide (Exhibition material at site SB1A). 


\title{
LIST OF SYMBOLS
}

$\mathrm{V}$
$\mathrm{R}$
$\mathrm{I}$
$\rho$
$\mathrm{k}$
$\mathrm{G}$
$\varepsilon$
$\varepsilon_{\mathrm{r}}$
$\mu$
$\mathrm{V}_{1}$
$\mathrm{~V}_{2}$
$\mathrm{~m}^{*}{ }^{*}$
$\mathrm{~m}^{2}$
$\gamma$
$\mathrm{k}$
$v$
$\alpha$
$\varepsilon$
$\mu$
$\sigma$
$\omega$
$\varepsilon_{\mathrm{R}}$
$\beta$

\author{
Voltage \\ Configuration resistance \\ Current \\ Resistivity \\ Geometric factor \\ Configuration factor \\ Dielectric permittivity \\ Relative dielectric permittivity \\ Magnetic permeability \\ Potential energy of layer 1 \\ Potential energy of layer 2 \\ Electron no. 1 effective masses \\ Electron no. 2 effective masses \\ Propagation constant \\ Wave number \\ Velocity \\ Attenuation constant \\ Dielectric permittivity \\ Magnetic permeability \\ Electrical conductivity \\ Angular frequency $=2 \pi \mathrm{f}$ \\ Relative permittivity \\ Phase constant
}




\section{LIST OF ABBREVIATIONS}

2-D

3-D

A.C

A.D

B.C

B.C.E

B.P

CGAR

DC

EM

ERT

etc.

GPR

IP

JMG

$\mathrm{L}$

PDP

R.D

$\mathrm{S}$

SP

UKM

USM

VLF
Two dimensional

Three dimensional

After Christ

Anno Domini

Before Christ

Before the common era

Before present

Centre for Global Archaeological Research

Direct current

Electromagnetic

Electric resistivity tomography

Et cetera

Ground penetrating radar

Induced polarization

Jabatan Mineral dan Geosains Malaysia

Long

Pole dipole

Relative date

Short

Spontaneous potential

Universiti Kebangsaan Malaysia

Universiti Sains Malaysia

Very low frequency 


\title{
APLIKASI GEOFIZIK DALAM PEMETAAN STRUKTUR SUBPERMUKAAN TAPAK ARKEOLOGI DI LEMBAH BUJANG, KEDAH, MALAYSIA.
}

\begin{abstract}
ABSTRAK
Lembah Bujang adalah salah satu kawasan arkeologi terpenting di Malaysia kerana ekskavasi di sini telah mendedahkan banyak kesan protosejarah. Ia merupakan salah satu tempat kegiatan tamadun tertua manusia di Semenanjung. Tujuan kajian ini adalah untuk memetakan dan mengetahui struktur subpermukaan kawasan kajian dari segi kepentingan arkeologi. Kaedah geofizik digunakan kerana tidak merosakkan dan tidak mengganggu tapak. Kaedah ini secara relatifnya lebih cepat dan hasilnya digunakan sebagai panduan bagi kerja penggalian seterusnya. Ia dapat membantu bagi menentukan kawasan galicari kerana kajian geofizik dapat mentafsirkan ciri bawah tanah yang penting seperti monumen, terowong atau dinding tertanam. Kaedah geofizik yang digunakan dalam kajian ini adalah kaedah gradiometer magnet, keberintangan 2-D dan radar penusukan bumi (GPR). Integrasi ketiga-tiga kaedah ini bermanfaat kerana masing-masing mempunyai kelebihan dan kekurangan. Kajian dijalankan di Sungai Batu dan hasilnya menunjukkan bahawa sedimentasi terdiri dari pasir, tanah liat dan batuan aluvium dengan kedalaman antara $0-15 \mathrm{~m}$, yang boleh dikaitkan dengan dasar monumen dibina daripada bata berasaskan laterit dan granit. Sedimentasi juga menunjukkan Sungai Batu merupakan sungai kuno. Sungai Bujang dibahagikan kepada tiga lapisan utama. Permukaan atas adalah campuran kolovium dengan pasir dan kerikil. Lapisan kedua adalah konduktif (aluvium marin) dengan kedalaman 1.5 - 3 m. Lapisan ketiga adalah pasir berlempung. Ekskavasi di Sungai Batu telah berjaya mendedahkan bukti arkeologi yang luar biasa iaitu tapak peleburan dan struktur senibina.
\end{abstract}




\title{
GEOPHYSICAL APPLICATIONS IN MAPPING THE SUBSURFACE STRUCTURE OF ARCHAEOLOGICAL SITE AT LEMBAH BUJANG, KEDAH, MALAYSIA.
}

\begin{abstract}
Lembah Bujang is one of Peninsular Malaysia's most important areas for archaeology as excavations in this area have revealed many traces of Malaysia's protohistory. The site is one of the oldest known place human civilization activities in the Peninsula. The aim of this study is to map and understand the subsurface structure of the survey area which is one of the archaeologically interesting areas. The specific areas of study are Sungai Batu and Sungai Bujang. Geophysical methods are used because it is non-destructive and non-invasive. The methods are relatively quick and the results are used as a guide for subsequent excavation work. So it can greatly helped in setting the digging priorities as geophysical surveying can reveal, for instance, important subsurface features like monuments, tunnels or buried walls. The geophysical methods used in this study were the magnetic gradiometer, 2D electrical resistivity and ground penetrating radar (GPR) methods. The integration of these three methods can be beneficial as each method has its strength and limitation. Sungai Batu site results show that the sedimentation consists of sandy clay, alluvium and boulders with a depth of $0-15 \mathrm{~m}$, which could be related to the base of the monument built of bricks made from laterite or granite. The sedimentation also proof that Sungai Batu was an ancient river. Sungai Bujang area divided into three subsurface layers. The top layer was the colluviums mix with some sand and gravels. Second layer was conductive layer (marine alluvium) with depth $1.5-3 \mathrm{~m}$. The third layer was clayey sand. Excavation work at Sungai Batu has successfully exposed remarkable archaeological findings which are iron smelting site and monument structure.
\end{abstract}




\section{CHAPTER 1 \\ INTRODUCTION}

\subsection{Background}

Archaeological sites become buried to depths varying between a few inches and tens of feet by the accumulation of soil through the action of wind, water or worms. Evidence for their existence can occur through the chance discovery of a scatter of pottery fragments on the surface following ploughing or through the chance exposure of walls or ditches when the topsoil is removed prior to development of buildings, roads and also agriculture. Alternatively, many new sites have been found by the deliberate visual examination of a region, either at ground level or from the air. Apart from the existence of obvious man-made features such as ramparts or ditches surrounding an Iron Age hill-fort, a series of shallow mounds and hollows, visible at ground level, could indicate the presence of a deserted mediaeval village (Tite, 1972).

Aerial photography provides the visual technique for the location of archaeological sites. Typically, crop-marks result from the different moisture conditions in the vicinity of buried features. Because of the lower moisture content of the soil, the crop above a buried wall ripens prematurely and therefore produces a lighter line on the photograph. In contrast, because of the higher moisture content above a ditch, the crop is richer in growth and is therefore darker in appearance. 


\subsection{Importance of archaeology}

Archaeological sites have developed into an essential part of the tourism industry in many countries of the world. In some countries, archaeological sites have not only become an important part of the tourism industry but also form a leading sector of the national income, earning millions of dollars every year. These include, amongst others, the terracotta army of China's first emperor in Xian, the ancient pyramids of Egypt and Central America, the stone age cave paintings of Lascaux in France, the ancient temples of Angkor in Cambodia, Borobudur in Indonesia and Ayutthaya in Thailand (Chia, 2003).

In Malaysia, intensive and systematic archaeological research during past 15 years or so, spearheaded by the Centre for Global Archaeological Research (CGAR) in Universiti Sains Malaysia, Penang has discovered many new sites and produced significant results and deepened our knowledge about the prehistory of Malaysia (Zuraina, 2003; Chia, 2003). The recent archaeological research had also began to renew interest in developing and promoting archaeology as a form of ecotourism but these efforts have been faced with numerous issues and challenges. One of the main issues is the need to conserve archaeological sites from destruction because of the rapid pace of economic development in Malaysia, especially in the past 10 years. Sites have been uncovered and damaged during major digging works such as the construction of highways, roads, opening of farmlands, building of dams and housing estates.

An important role that archaeology can play is to educate the public on the importance and the need to save our cultural heritage. More importantly, there is an urgent need to introduce sustainable development and management of 
archaeological sites in order to provide long-term economic benefits for the ecotourism industry and to preserve the cultural heritage of Malaysia.

The modern archeology has developed into a scientific study that involves many areas of science study such as geology, chemistry, physics, biology and medicine to get as much information about the artifacts, archaeological sites and events (Mokhtar, 2010).

\subsection{Non-destructive prospecting}

Exploring a site by destructive means, such as invasive excavation, often does not reveal the historical information from a site that archaeologists are trying to determine. In the case where a large burial mound has already been designated a historic site, various measures such as preservation and landscaping have already been initiated. These particular burial mounds are usually unavailable for archaeologists to probe by destructive excavation. When requests for studying protected burial mounds of the tumulus period are received, such as those that come in from academic institutions, the only available means to study these mounds are with remote prospection methods. Burial structures such as those found in Japanese tumuli, include unique features such as vertical chambers, clay coatings over wooden coffins and various stone chambers which have extended corridors and entrances. Many of these features of interest can be imaged from prospection surveys. These essential features of the mounds can help archaeologists to better understand the historical value of the tumuli remotely - without employing destructive excavation.

Sometimes prospection is conducted by a single geophysical method and sometimes with little success in detecting the subsurface targets of interest. Because 
prospection is a non-destructive method, it is also possible to reoccupy the site again and use a different geophysical tool for probing which may be more effective. Prospection differs from excavation in that you can keep choosing another method over and over till you get the necessary information, whereas excavation can only be conducted once. It is empirically known that results may differ according to hygroscopic conditions and vegetation coverage of a site even if the same prospection method is being used. The possibility of also returning to a site during different seasons can sometimes also help to decipher the subsurface structures present.

As has been previously stated, there is a limit to the effectiveness of prospection, but it can nonetheless provide the necessary information concerning a variety of underground structures that archaeologists are after. If prospection is to be employed in the study of a site, it is necessary to properly set the objective of the prospection and use the prospection tool that best matches the objective. It is also often required to employ multiple geophysical methods in order to properly meet the survey objective.

Each respective method of prospection helps determine "foreign objects" buried within the soil based on measuring contrasting physical factors with surrounding soils. Consequently, if the results obtained by different methods are classified and reported, these methods can be known through experience to be reliable or unreliable prospection methods for detecting targets buried in specific subsurface ground soils. The various geophysical methods available all relay separate and distinct information about subsurface targets. It often is the case that 
information obtained from one method is insufficient for interpretation, whereas together with another method, may help the archaeologist discover the buried past.

\subsection{Geophysics in archaeology}

In archaeology, geophysical methods had been applied usually in a qualitative form, limited only to the use of filters that enhance the data display (Argote, 2009). The main objective in this work is the implementation of modelling techniques that allows us to reconstruct the geometry of buried bodies and the determination of their depths.

Geophysics in archaeology is fundamentally concerned with the identification of contrast between materials inside and outside of archaeological structures. If there are underground remains, these can have an effect on the surface of the ground which can cause variations in ground dryness and vegetation growth. The comparison between soils outside of the buried features and those inside or contained within the feature, differences in electric resistance, electrical conductivity, dielectric permittivity as well as magnetic susceptibility can exist. By measuring these physical changes in electromagnetic properties across buried features, there is a possibility of detecting subsurface remains.

Geophysical application in archaeology is not a brand new discipline. It is often referred to an underground mapping used for archaeological mapping. In such study, jargons like "archaeological geophysics", "archaeogeophysics", and even "geophysical prospection" are generally synonymous. Here, archaeogeophysics perhaps is the most suitable and descriptive term. 
For decades, geophysical methods have been one of the most useful methods and are widely used in archaeology to image the underground of archaeologically interesting areas prior to excavation. Thus, geophysical survey is normally conducted as a preliminary study for archaeological purpose. Moreover, geophysics is also beneficial in other fields such as engineering, environment, hydrology, geology, volcanic, also in oil and gas industry. Pressures by developers, and the public growing sensitivity towards the preservation of historic and prehistoric cultural artifacts and sites, has led to an accelerating use of high resolution geophysical methods in the archaeological science (Wynn, 1986). Romig (1996) stated that in the future, the need to use the earth more wisely to support a burgeoning global population will require the ability to see inside the earth more clearly and accurately. Thus, this will increase the value of geophysical information.

Geophysics is a large scale of study and has many sub-disciplines below it. Generally, geophysics is the study of the earth by quantitative physical methods, especially by seismic reflection and refraction, gravity, magnetic, electrical, electromagnetic, and radioactivity methods. It is also known as the application of physical principles to studies of the earth, including the branches of (a) seismology (earthquakes and elastic waves); (b) geothermometry (heating of the earth, heat flow, volcanology, and hot springs); (c) hydrology (ground and surface water, sometimes including glaciology); (d) physical oceanography; (e) meteorology; (f) gravity and geodesy (the earth's gravitational field and the size and form of the earth); (g) atmospheric electricity and terrestrial magnetism (including ionosphere, Van Allen belts, telluric currents, etc.); (h) tectonophysics (geological processes in the earth) ; and (i) exploration, engineering, and environmental geophysics. Geochronology (the dating of earth history) and geocosmogony (the origin of the 
earth) are sometimes added to the foregoing list. However, geophysics is often refers to solid-earth geophysics only, thus excluding (c), (d), (e), and portions of other subjects from the above list. Then, when we talk about exploration geophysics, it is the use of seismic, gravity, magnetic, electrical, electromagnetic, etc., methods in the search for oil, gas, minerals, water, etc., with the objective of economic exploitation (Sheriff, 2002).

According to Thomas and Kelly (2009), archaeology is the study of the past through the systematic recovery and analysis of material remains. It was not until the middle of the $19^{\text {th }}$ century that the discipline of archaeology became truly established. Already in the background there were the significant achievements of the newly developed science of geology. The Scottish geologist James Hutton (17261797), in his Theory of the Earth (1788), had studied the stratification of rocks. Their arrangement in superimposed layers or strata is establishing principles which were to be the basis of archaeological excavation. Hutton (1788) showed that the stratification of rocks was due to processes which were going on in seas, river and lakes. This was the principle of "uniformitarianism". It was argued again by Charles Lyell (1797-1875) in his Principles of Geology (1833): that geologically ancient conditions were in essence similar to, or "uniform with", those of our own time. This idea could be applied to the human past also, and it marks one of the fundamental notions of modern archaeology: that in many ways the past was much like the present.

Archaeologists have always used limited surface collection of artifacts as one way of trying to access the date and layout of a site prior to excavation. However, now that surface survey has become not merely a preliminary to excavation but in 
some instance a substitute for it - due to cost and other reasons, a vigorous debate is taking place in archaeology about how far surface traces do in fact reflect distribution below ground (Bahn and Renfrew, 2004).

The most widely practiced method in archaeological prospection is identification of ancient occupation from interpretation of aerial photographs. Resistivity began being used immediately after World War II, followed by magnetic and ground-penetrating radar (GPR). Other methods such as electromagnetic (EM) method and seismic method have recently been applied.

Table 1.1 provides an overview of the common surface geophysical methods. There are many exceptions to this table and many variables that dictate the applicability of each method. Noted that "A" implies a primary choice of method and "B" implies a secondary choice or alternative method.

For archaeological features, it shows that electromagnetic methods such as frequency domain and ground penetrating radar, also potential methods that is magnetic method are the primary choice of methods that can be applied. While seismic and electrical methods could be used as alternative method. In archaeological investigations, the most common interests are to do the inspection of historic and archaeological sites, and also to study the location of burial sites and graves. Final selection of the methods should be done by experienced, qualified professional who can take into account all of the site-specific conditions. 
Table 1.1: Summary of applications for common surface geophysical techniques (Technos, 2004).

\begin{tabular}{|c|c|c|c|c|c|c|c|c|c|c|c|}
\hline & \multicolumn{4}{|c|}{ Electrical } & \multicolumn{5}{|c|}{ Electromagnetics } & \multicolumn{2}{|c|}{ Potential Methods } \\
\hline $\begin{array}{l}\text { Applications } \\
\text { Natural Geologic } \\
\text { Hydrologic Conditions }\end{array}$ & $\begin{array}{l}\text { DC } \\
\text { Resistivity } \\
\text { Imaging }\end{array}$ & $\begin{array}{c}\text { Capacitively- } \\
\text { Couple } \\
\text { Resistivity } \\
\text { Imaging }\end{array}$ & IP & SP & $\begin{array}{l}\text { Frequency } \\
\text { Domain }\end{array}$ & $\begin{array}{c}\text { Time } \\
\text { Domain }\end{array}$ & $\begin{array}{c}\text { Metal } \\
\text { Detectors }\end{array}$ & VLF & GPR & Magnetics & Microgravity \\
\hline Soil/unconsolidated layers & A & A & B & & $\mathrm{B}$ & B & & & $\mathrm{A}$ & & \\
\hline Rock layers & $\mathrm{B}$ & $\mathrm{B}$ & $\mathrm{B}$ & & & $\mathrm{B}$ & & & $\mathrm{B}$ & & \\
\hline Depth to bedrock & $\mathrm{A}$ & $\mathrm{A}$ & $\mathrm{B}$ & & B & $\mathrm{B}$ & & & $\mathrm{A}$ & & $\mathrm{A}$ \\
\hline Fractures and fault zones & B & B & $\mathrm{A}$ & $\mathrm{A}$ & $\mathrm{A}$ & B & & $\mathrm{A}$ & $\mathrm{A}$ & B & B \\
\hline Void and sinkholes & B & $\mathrm{B}$ & & $\mathrm{B}$ & $\mathrm{B}$ & & & & $\mathrm{A}$ & & $\mathrm{A}$ \\
\hline Soil and rock properties & $\mathrm{B}$ & $\mathrm{B}$ & B & & $\mathrm{B}$ & & & & & & $\mathrm{B}$ \\
\hline Dam and lagoon leakage & B & B & & A & B & & & & B & & \\
\hline \multicolumn{12}{|l|}{ Inorganic Contaminants } \\
\hline Landfill leachate & A & B & $\mathrm{B}$ & & $\mathrm{A}$ & $\mathrm{A}$ & & & B & & \\
\hline Saltwater intrusion & A & $\mathrm{B}$ & B & & $\mathrm{A}$ & $\mathrm{A}$ & & & B & & \\
\hline \multicolumn{12}{|l|}{ Organic Contaminants } \\
\hline $\begin{array}{c}\text { Light,nonaqueous phase } \\
\text { liquids }\end{array}$ & $\mathrm{B}$ & $\mathrm{B}$ & B & & $\mathrm{B}$ & & & & $\mathrm{B}$ & & \\
\hline \multicolumn{12}{|l|}{ Manmade Buried Objects } \\
\hline Utilities & & & & & $\mathrm{B}$ & & $\mathrm{A}$ & & $\mathrm{A}$ & $\mathrm{B}$ & \\
\hline Drums and USTs & & & & & $\mathrm{A}$ & & $\mathrm{A}$ & & $\mathrm{A}$ & $\mathrm{A}$ & \\
\hline UXO & & & & & & & $\mathrm{A}$ & & B & A & \\
\hline Abandoned wells & & & & & & & $\mathrm{B}$ & & & A & \\
\hline $\begin{array}{l}\text { Landfill and trench } \\
\text { boundaries }\end{array}$ & $\mathrm{B}$ & $\mathrm{B}$ & B & & A & $\mathrm{B}$ & & & A & B & \\
\hline Archaeological features & $\mathrm{B}$ & $\mathrm{B}$ & & & $\mathrm{A}$ & & & & $\mathrm{A}$ & $\mathrm{A}$ & $\mathrm{B}$ \\
\hline
\end{tabular}

Note: "A" implies a primary choice of method. "B" implies a secondary or alternative method. 
If there is a need to take measures to preserve an archaeological site after finding out about its contents from excavating, it cannot be known if the site has been irrevocably destroyed by removing dirt from an excavation. The possibility of understanding the complete story of the site can only be investigated if the site remains intact.

In cases such as this, it is possible to obtain the pertinent information needed for preservation using a non-destructive method of prospection. Many features that are obtained from excavation can also be detected remotely through prospection. Prospection is most useful for helping archaeologist extrapolate what is known about a site into unexcavated areas. For example, if one is trying to extend the location of a ditch from an excavated area into an unexcavated area, prospection can be adequately employed in tracing the ditch. Prospection surveys in similar kinds of applications have a high probability of success.

In the case of preserving archaeological sites designated as historical sites, it is first necessary to secure the area and determine its boundaries. Discovering the boundaries circumscribed by a site such as mapping a channel or rampart that may surround a settlement, is a relatively easy task that prospection can be used for. If the target is large, it can normally be identified even if it is buried deep in the ground. In the case of discovering channels or ditches, if these buried structures are also saturated with water, electromagnetic contrasts are even higher than if the structures were dry, making for easy identification from geophysical remote sensing.

Many targets associated with settlements are often difficult to identify though. Small postholes are especially difficult and often remained insufficiently 
detected on most surveys. However, even if the individual postholes remain unmapped on the survey data, settlement floors and boundaries are still often discovered because of variations in materials or soil compaction measured within and outside of the settlements. Test trenching over suspected remains mapped from the survey data can help to calibrate datasets for a site and aid in determining the distribution of occupation of a site. Boring can also be used in these cases to minimize the site destruction as well.

\subsection{Statement of problem}

In archaeogeophysics, the main concern is about multifarious methods of geophysics which are now playing an increasingly important role. In Malaysia, the integrated study of geophysical methods application to archaeology is very few compared to other region which was initiated in the middle of the $19^{\text {th }}$ century, when archaeologist discovered that the existence of underground remains could be detected using geophysical methods on the surface. Thus, more efforts and initiates need to be done to expand the contribution of geophysics study.

Since the historical importance of remains in Lembah Bujang is very critical, lots of work needs to be done in order to get a proper record and methods to preserve our heritage. Lembah Bujang is known to be one of the important ancient trading centres in Southeast Asia (Allen, 1991). Geophysics plays an important role in assisting archaeologist to get a good preliminary result before they proceed with the excavation and digging works. Since geophysical method is non-destructive and archaeological digging could be destructive to the subsurface artifacts so survey will be employed to map the subsurface prior to excavation. 
It is very important to know about Lembah Bujang chronology as previous studies were not done systematically and lack scientific proof. There is no record about absolute dating and scientific study, which leads to the non holistic interpretation.

Research using geophysical method was previously done by a group from Universiti Kebangsaan Malaysia using resistivity method, with Dipole-dipole array at Sungai Mas, Lembah Bujang (Abdul Rahim and Umar, 1999). Magnetic method could not be applied during that time because the survey was done in a residential area where there are many manmade disturbances such as fences and houses. In 2-D resistivity survey, the UKM researchers used Dipole-dipole array. For this study, Pole-dipole array will be implemented.

The objective of this research is to identify the best sequence of geophysical methods that can be applied effectively in this area to map out and reconnaissance the big picture of the whole Sungai Batu area. For reconnaissance survey to cover large area, magnetic survey will be used. Then, it is effective to design the survey plan for another geophysics method such as 2-D resistivity survey with suitable array. Ground penetrating radar method is then used to map shallow target up to 10 m for detailed study.

\subsection{Objective of study}

The objective for archaeological site surveys and excavation research is to collect historical information from archaeologist sites, structures and relics buried in the ground by digging. If the condition of what is below the ground can be determined prior to digging, an excavation plan can be suitably formulated and large 
quantities of accurate information can be collected. This can both save time and money in understanding and discovering a site.

According to Bahn and Renfrew (2004), generally, excavation by definition retains its central role in fieldwork because it yields the most reliable evidence for the two main kind of information archaeologist are interested in:

i. Human activities at a particular period in the past; and

ii. Changes in those activities from period to period

Very broadly, it can say that contemporary activities take place horizontally in space, whereas changes in those activities occur vertically through time.

Archaeological evidence has proven that Lembah Bujang is amongst the richest archaeology sites in Malaysia and served as primary coastal centres that managed substantial internal and external exchange networks. Geophysical methods such as magnetic gradiometer survey, 2-D resistivity and ground penetrating radar have been used widely in the study. Hence, fully implementation of those geophysical techniques will help the ancient artifacts to be located, mapped and characterized.

Hence for Sungai Batu and Sungai Bujang area, the primary objectives of this study are:

i. To map the subsurface and detect the type of soil.

ii. To map the ancient river that is believed to be occupied.

iii. To detect the location of ancient archaeological monument in Lembah Bujang area prior to excavation by archaeologist. 
In this study, magnetic gradiometer and resistivity methods will be the main methods, assisting by ground penetrating radar. Meanwhile, the depth and size of the target body could also be estimated.

\subsection{Scope of study}

In this study, mainly magnetic gradiometer and 2-D resistivity methods will be used. Ground penetrating radar also will be manipulated as additional data in order to get a more detail result. Therefore, these three geophysical methods will be correlated accordingly.

Magnetic gradiometer data used as the regional study of the area to get a big picture, and from the magnetic anomaly, 2-D resistivity survey with modified Poledipole array will be conducted to study more details followed by GPR method to get cross section for shallower sub surface. This modified Pole-dipole array has sensitivity to horizontal and vertical variation compare to some other arrays (Rosli, 2009). The software used for magnetic gradiometer is Microsoft Excel and Surfer 8.0 for map contouring, while RES2DINV used for 2-D resistivity imaging data processing. For ground penetrating radar data, GroundVision software was used for processing.

\subsection{Layout of thesis}

Generally, the outline of this thesis is organized as follows. In Chapter 2, the literature reviews related to archaeogeophysics which were using the same methods and previous studies done at research area are compiled. This chapter also includes the background of Lembah Bujang area and the significant of this location to the importance of local history and the importance of studying its archaeology. 
Chapter 3 will discuss about the materials and methods used including the theory and principle of methods used in this study, which is magnetic gradiometer, 2D resistivity and ground penetrating radar are briefly explained. It is then followed by data acquisition and study area. The data acquisition of magnetic gradiometer, 2D resistivity imaging and ground penetrating radar methods are explained in with respect to the parameter used, survey design and any related matters.

Chapter 4 is assigned to present the results and also the discussions of geophysical survey using magnetic gradiometer, 2-D resistivity imaging and ground penetrating radar at Lembah Bujang in much more details.

Finally is Chapter 5, conclusion of the magnetic gradiometer, 2-D resistivity imaging and ground penetrating radar study were discussed. Recommendations and suggestions for future research also included.

\subsection{Chapter summary}

The reseach study was conducted in Lembah Bujang, southern Kedah including Sungai Batu and Sungai Bujang area which is known as one of the richest archaeological site in Peninsular Malaysia. Therefore, the primary objective of this study is to locate the ancient archaeological monument in Lembah Bujang area prior to excavation by archaeologist, using geophysical methods that is magnetic gradiometer, 2-D resistivity and also ground penetrating radar method. Archaeological site are normally less than $3 \mathrm{~m}$ in depth.

It must also be aware that archaeology is giving an economy impact to the country. Lembah bujang is one of a good evident that gives positive economic impact of large-scale archaeological projects. When the local communities concern about their heritage and show the interest, then the local historic resources will have 
an economic generation through tourism. This is also a good contribution to archaeogeophysics research in Malaysia.

In this study, the three geophysical methods that is magnetic gradiometer, 2D resistivity and also ground penetrating radar method have been used, because the previous study in Lembah Bujang used different approach. For 2-D resistivity imaging, different array that is modifies Pole-dipole is used with additional of gradiometer magnetic and ground penetrating radar. 


\section{CHAPTER 2}

\section{LITERATURE REVIEW}

\subsection{Introduction}

The most widely practiced method in archaeological prospection is identification of ancient occupation from interpretation of aerial photographs. This method was initiated in the middle of the $19^{\text {th }}$ century, when archaeologist discovered that the existence of underground remains could be determined by the effect that subsurface remains have on the immediate ground surface. Crawford, who systematized this method primarily in the 1920s, contributes largely to the popularization of photograph interpretation (Nishimura, 1997). Resistivity began being used immediately after World War II, followed by magnetic survey and ground penetrating radar (GPR). Other methods such as electromagnetic method (EM), as well as seismic methods have recently been applied.

\subsection{Previous study}

The previous study using magnetic method was done at Bukit Bunuh, Lenggong in Upper Perak with different attempts, which is to find the old river. The mapping of meteorite impact structure at Bukit Bunuh was successfully done. Bukit Bunuh is another archaeological important site founded by Centre for Global Archaeological Research. From the dating it is believed to be the oldest archaeological site in Malaysia. This site has been occupied during 1.83 million years ago as hand axe were found embedded in the suevite (Mokhtar, 2011). The artefacts were found embedded in suevite rock, formed as a result of the impact of meteorite crashing down at Bukit Bunuh. There are also quite a number of published 
and unpublished papers of geophysics survey done for archaeological purpose in Universiti Sains Malaysia.

The research using magnetic method was employed in Upper Perak with the main objective to determine the nature of the ancient river system, which is old Sungai Perak, in the subsurface of the Upper Perak area (Khairul Ariffin, 2007). This magnetic survey covers mainly the district of Upper Perak including Pengkalan Hulu, Grik, Lawin, Lenggong and Kuala Kangsar. The results show generally, the river trend of the ancient river is on the low magnetic region, while existing river is on the high magnetic region. The magnetic values shown are approximately due to sediment composition. The ancient river alignment approximation is based on old river gravel observed at archaeological excavation site. From the survey result, the magnetic values generally increase towards south of Upper Perak and increase from the west to the east at the north of Upper Perak. As assumed, the changes in ancient river alignment compared to the present Sungai Perak are basically concentrated at the north area. Anomalies of magnetic significantly show different sedimentary thickness and its comparison.

Generally, there is a close correlation between the gravity and magnetic anomaly pattern and the general geology of the survey area. The largest anomalies are caused by the Main Range granite and its offshoots (Bintang Hill), while the lowest anomalies correspond to the sedimentary rock, especially at Lawin and Lenggong area. In sedimentary covered areas, the gravity and magnetic data has proved useful in detecting major changes in the bedrock lithology which is related with the igneous activity. This is important to study the environment history 
especially rivers evolution and sedimentary basin. Therefore, the evolutions of the river at Upper Perak were distinguished.

The geophysical study of Lembah Bujang area was conducted by Department of Geology from Universiti Kebangsaan Malaysia (UKM) in the 90's. Three archaeological sites containing different artifacts were investigated by geophysical methods. The first site is located at Kampung Sungai Mas in Kuala Muda, District of Kedah. Since the beginning of the 1980 this site has produced a number of important and interesting archaeological finds relevant to the history of Lembah Bujang. The archaeological teams from UKM and Museum Department of Malaysia revealed that there were several remains consisting of low mounds of laterite block and brick foundation for structures in the village. A geoelectrical profiling method using dipole-dipole array was used to study the artifacts and locating anomalies of archaeological significance in the area. Result of the study indicates that the geoelectrical resistivity method can be successfully used in detecting archaeological anomalies of shallow buried artifacts in the study area (Abdul Rahim and Umar, 1999).

The second site is situated in a fisherman's village on the northern bank of Kedah River mouth and it lies in a coastal lowland area of Kuala Kedah. The site is located approximately $7 \mathrm{~km}$ from Alor Star, northern Kedah. It covers an area of about 3.5 hectares along the river side. Remains of partly buried $19^{\text {th }}$ century fort which belongs to the former sultan of Kedah was excavated by the Museum Department of Malaysia for future conservation plan. The area was gazetted as a museum reserve and planned to be developed as another historical tourist spot in Kedah. Geophysical measurements employing geoelectric profiling using Wenner 
array and magnetic surveys were conducted to locate structure of partly buried foundation of the fort as a guide for future conservation work. Both the geoelectrical and magnetic surveys have produced results showing several anomalous areas which appear to coincide well with the locations of the uncovered artifacts.

The third archaeological site is located at the area of Pasir Salak historical complex in Kampung Gajah District, southern Perak. It was identified to be a site of a former fort built by a Malay warrior to fight the British in the late of $19^{\text {th }}$ century. The department of museum has conducted four phase of excavation in the 90's but no significant major artifacts was found. Detailed geophysical study (geoelectric and magnetic) was carried out to look for artifact. The geoelectric profiling survey employing dipole-dipole array revealed eight different locations of high resistivity zones whereas the magnetic measurement indicated two anomalous areas. These anomalous areas could probably be associated with the artifact of archaeological significance and they need to be confirmed by excavation (Abdul Rahim and Umar, 1999).

There is an interesting study done in Taiwan using magnetic method in archaeology investigation. The result state that the magnetic method can be efficiently applied to archaeological investigation especially when the signal to noise $(\mathrm{S} / \mathrm{N})$ ratio is enhanced appropriately. This study presents a model experiment and field examples of magnetic exploration in archaeology. By using appropriate measuring processes and filtering methods, the conventional and more recent magnetic prospecting techniques are successfully applied to the very shallow, smallscale investigations, which are used to locate and map archaeological targets. They focus on mapping the buried slate caskets in the alluvial environment, which are the 
most commonly encountered and readily preserved ones at the archaeological sites of Taiwan. The gradiometry and the inferred derivatives may resolve individual anomalies. Locations of the maxima determined by the 3-D analytic signals can be used to describe the outlines of the bodies that cause the anomalies. Furthermore, the susceptibility was very successful in mapping near-surface targets at the Chubin site. The magnetic results of the example at the Hutzushan site compared to the GPR survey carried out by previous investigators; indicate that the GPR anomalies may be caused by other sources (Lee et al., 2003)

The magnetic response of a casket displayed in various ways, depending on the pole distribution of the casket, the geometry, the magnetization direction and the orientation of buried casket. The processing methods may improve the data resolution but precautions must be taken for the artifacts.

An analysis with case examples has been made of the feasibility of archaeological investigation using integrated signal enhancements in searching for slate caskets in a small scale shallow alluvial environment. The techniques are based on approaches commonly used in regional and deep magnetic surveys. With appropriate field parameter design and filtering process, the conventional methods can be successfully applied to archaeological investigation on the fine scale. As the data has presented, the survey areas may effected by a variety of noises. To improve the resolution of magnetic data, a number of methods can be considered. While one technique may not yield a visible anomalous signal, an integrated method reveals the areas where known caskets are located. Among the techniques are presented, the vertical gradient measurement which is effective in delineating the shallow causative sources with minimum post-processing and 3-D analytical signal has maximum 
advantage of detecting the boundaries of the buried target. As the signal enhancement techniques used in this study all involve derivatives of the magnetic anomalies, noise may be enhanced as well; therefore, obsessive processing is not suggested because each step of signal enhancement may introduce one kind of artifacts in return. To improve the $\mathrm{S} / \mathrm{N}$ ratio, a filtering procedure is needed for data with noticeable noise. However, filtering may attenuate the signals as well if the two frequency bands overlap each other. They suggest that a filtering procedure should be rendered with caution. A trial-and-error approach to implement an adequate filter is recommended.

Another example of successful application of geophysics method was done in Tel Yavne in Israel, the site of the ancient city of Yavne. In preparation for excavation work at a later date, electrical resistivity tomography (ERT) surveys, ground penetrating radar surveys and low altitude photography from kites and balloons were carried out. This paper discussed the ERT and photographic surveys. The objectives of these two surveys were to delineate the plan view and vertical extent of accumulated cultural debris, and to identify particular areas for initial test pitting by archaeologists. Eight ERT cross-sections were imaged, ranging in length from 80 to $140 \mathrm{~m}$. Approximately 500 low altitude photographs were shot. Specific features possibly identified include a 9th century B.C.E. (before the common era) water system, the Philistine city wall dating from 790 B.C.E., the ruins of a 12th century C.E (common era). Crusader castle, and numerous architectural features from the Mameluke, Ottoman, and Palestinian periods of habitation. This is the first time that non-destructive techniques have been used in the first phase of an archaeological exploration program in Israel at such an important, well recognised ancient site. 
There is another successful archaeogeophysics study in Arkansas, southern region of the United States done in 2002 titled Archaeogeophysics and Archaeology at a Caddo Mound Center in Southwestern Arkansas: The Tom Jones Site (3HE40) at Grandview Ranch by Jami J. Lockhart and Frank F. Schambach from Arkansas Archaeological Survey (Lockhart and Schambach, 2002).

The area known as Grandview Ranch is located in Hempstead County near Hope, Arkansas, in the southwestern part of the state. This 4885 -acre property is the Grandview Prairie Wildlife Management Area. The property had been protected from development and from looters by its previous owners. As a consequence, numerous historic and prehistoric archaeological sites within the boundaries of Grandview Ranch remain largely undisturbed and many are in pristine condition.

As part of the archaeological research design, selected parts of the Tom Jones site were explored using archaeogeophysical equipment for near-surface prospection. Archaeogeophysics in conjunction with pinpointed excavation and analysis provides our best chance to discover the constructed and even the conceptualized components of cultural landscapes - landscapes built by people and also invested by them with often profound cultural meaning. The range of technologies employed, together with the simultaneous excavations that allowed us to "ground-truth" the computergenerated imagery, made this project the first full-scale test of geophysical remote sensing for archaeological research in Arkansas, and among the first in the Southeast region. The archaeogeophysical aspect of the Grandview research is directed by Lockhart (2002).

The Tom Jones site is a Caddo mound centre consisting of a temple mound and at least five outlying mounds. Based on the evidence gathered, it appears that the 
Tom Jones site was occupied until approximately 500 years ago. Occupation probably reached its zenith during the latter part of the three centuries bracketed by A.D. 1200 and 1500. Chronometric dating of features is underway. Grandview Ranch is located within the archeogeographic province of the Trans-Mississippi South, which is characterized as a marginal southeastern woodland environment.

An integral component of this intrasite portion of the study entails large-scale contiguous coverage of the site using a variety of geophysical survey equipment. Fifteen $20 \times 20 \mathrm{~m}$ geophysical grid units have been surveyed using electrical resistance, electromagnetic conductivity, magnetic susceptibility, and magnetometry (gradiometry). Initial results appear very favourable both for the location and identification of buried structures and other features using these techniques.

For a closer look at just one of the $20 \times 20 \mathrm{~m}$ squares in this group, compare the imagery from all four techniques - magnetic susceptibility, gradiometry, electrical resistance, and electromagnetic conductivity. Each technique measures different physical properties, but all four indicate similar anomalies. The signature in the lower left of each image was interpreted as a structure with massive burning. The anomaly in the upper center - most noticeable in the magnetic susceptibility and gradiometry - was interpreted as the wall line of another structure with a central hearth.

To test these interpretations, excavation units were "pinpointed" over the anomalies by locating georeferenced points within the imagery and using a Total Station transit to position them precisely on the ground. The excavations revealed that there was indeed a burned prehistoric structure. There is a massive concentration of fired clay or burned daub that was responsible for the large magnetic readings in 
the geophysical image. A number of ceramic vessels were associated with this structure, including a large jar upended over a deer scapula. Geophysical survey over larger areas of the Tom Jones site and at similar sites should help answer any other important questions.

In Turkey, three geophysical methods which are GPR, ERT and magnetic have been used in investigations inside the Martyrium of St Philip, Hierapolis. Hierapolis, Denizli, Turkey was one of the most important Hellenistic-Roman cities in Asia Minor. Located about $250 \mathrm{~km}$ east of Izmir, the area is a UNESCO World Heritage Site because of its magnificent archaeological remains and the white traver tine pool formations created by its peculiar geothermal setting (Nuzzo et al., 2009).

In 2001-2003 geophysical surveys were performed by the University of Lecce in several areas inside the archaeological site of Hierapolis to support the archaeological excavations. This paper reports the results of the integrated geophysical surveys performed in 2003 inside the Martyrium of Saint Philip, a mausoleum built on the place where it is believed that the Apostle was martyred.

Ground-penetrating radar (GPR), electrical resistivity tomography (ERT) and magnetic gradient investigations were carried out in the central octagonal room, whereas the accessible lateral rooms were surveyed with GPR and occasionally ERT. The acquisition was performed along a series of closely spaced lines and the processed data were visualized as two-dimensional vertical sections (GPR), map view (magnetic gradiometry), depth slices or three-dimensional volumes (GPR and ERT) to allow an integrated interpretation of the geophysical results. 